\title{
SZEMLE
}

\section{Az Anabaena cianobaktérium nemzetség biotechnológiai felhasználása és taxonómiai áttekintése}

\author{
HORVÁTH Nándor ${ }^{1}$, MOLNÁR Zoltán ${ }^{1}$ és ÖRDÖG Vince ${ }^{1,2}$ \\ ${ }^{1}$ Nyugat-magyarországi Egyetem, Mezőgazdaság- és Élelmiszertudományi Kar, \\ Növénybiológiai Intézet, 9200 Mosonmagyaróvár, Lucsony u. 15-17.; \\ horvathnandor@windowslive.com \\ ${ }^{2}$ University of KwaZulu-Natal, School of Biological Sciences, Pietermaritzburg Campus, \\ 3209 Scottsville, Private Bag X 01, South African Republic
}

Elfogadva: 2016. február 25.

Kulcsszavak: Anabaena, biotechnológia, cianobaktériumok, filogenetika, kékalga, taxonómia.

Összefoglalás: A cianobaktériumok alkalmazási területei rendkívül változatosak, különösen a mezőgazdaságban, az élelmiszer-kiegészítők piacán és a biotechnológiai iparban terjedtek el, de szerepük a biológiai szennyvíztisztításban is egyre nagyobb. Továbbá ismert, hogy bioaktív vegyületek széles skáláját is képesek megtermelni. A cianobaktériumok rendszertani helyének megállapítása korábban morfológiai jellemzők alapján történt. A molekuláris módszerek fejlődése magával hozta a morfológiai és molekuláris meghatározás együttes alkalmazását. Ma a taxonómiai rendszerezés már a kombinált, ún. „polifázikus” megközelítést alkalmazza, ugyanis a fajok azonosításánál molekuláris, morfológiai, fiziológiai, citológiai, toxikológiai és ökofiziológiai adatokat is figyelembe vesznek. A múltban leírt taxonok közül számos jelenleg nem elfogadott és még nagyon sok szorul revízióra. A „Süßwasserflora von Mitteleuropa” határozókönyv megközelítőleg 84 Anabaena fajt tart nyilván. Nagyon sok (116), korábban Anabaena néven szereplő cianobaktérium más nemzetségekbe került át, jelenleg 49 a Dolichospermum, 42 a Trichormus, 15 a Chrysosporum 10 pedig a Sphaerospermopsis nemzetségekhez tartozik. Az internetes Algabase (http://www.algaebase.org/) 503, míg az NCBI (http:// www.ncbi.nlm.nih.gov/) adatbázis 559 Anabaena taxont tartalmaz. Jelen szemlecikk áttekintést ad az Anabaena nemzetség fajainak kísérleti és biotechnológiai alkalmazásáról, valamint áttekinti taxonómiai kutatásuk legújabb eredményeit.

\section{Bevezetés}

A cianobaktériumok (Cyanobacteria) Gram-negatív, oxigéntermelő fotoszintetikus prokarióták hosszú evolúciós történettel (FAY és VAN BAALEN 1987). 
Ezen fotoautotróf baktériumok, a metabolikus képességek és adaptív mechanizmusok széles választékával rendelkeznek, beleértve a molekuláris nitrogén megkötését és a kromatikus adaptációt (a járulékos pigmentek megfelelő arányban való szintézisével képesek alkalmazkodni környezetük fényviszonyaihoz, BRYANT 1994). Sejtjeik színe a kékeszöldtől a vörösig változik.

A fotoszintetizáló élőlények között, a cianobaktériumok népesítik be az élőhelyek legszélesebb körét. Megtalálhatók hideg és meleg, lúgos és savas, édesvízi, sósvízi, szárazföldi, és szimbiotikus környezetben (AHMED et al. 2010). A cianobaktériumok képesek az alapvető tápelemek és anyagcseretermékek raktározására (FAY és VAN BAALEN 1987). Kizárólag a cianobaktériumokra jellemzőek a nitrogénraktárként is szolgáló cianoficin szemcsék, amelyek a citoplazmában a tilakoidmembránok között helyezkednek el (CHORUs és BARTRAM 1999). A cianobaktériumok képesek vízvirágzás okozására eutróf tavakban, rendszerint a meleg nyári időszakban. Ezeket a tömegprodukciókat általában gázvakuólummal bíró nemzetségek (Anabaena, Aphanizomenon, Microcystis és Planktothrix) váltják ki.

Jelen szemlecikkünk áttekintést nyújt az Anabaena nemzetségben rejlő lehetőségekről, amelyek életképes megoldásokat biztosíthatnak a globális élelmiszer-, energia- és környezeti problémákra, majd ismerteti a nemzetség rendszerezésének helyzetét modern polifázikus megközelítésben.

\section{Az Anabaena nemzetség jelentősége a gyakorlati felhasználás szempontjából}

A globális felmelegedés és a fosszilis tüzelőanyagok fogyása erős ösztönzést biztosít a nem fosszilis alternatívák alkalmazásainak irányába. Felismerték, hogy a növények általi bioüzemanyagok előállítása nem fedezi a növekvő energiaigényeket. Így jutnak mind nagyobb szerephez olyan fotoszintetizáló egysejtủ vagy telepes élőlények, amelyek ígéretes alapanyagnak bizonyulnak. A Gloeocapsa, az Anabaena, az Arthrospira/Spirulina, a Cyanothece és a Nostoc nemzetségekhez tartozó cianobaktériumokról már korábban bebizonyosodott, hogy hidrogén elöállítására képesek (AKKERMAN et al. 2002). RAI és MALLICK (1992) a bioremediáció (a szennyezett talaj, talajvíz, felszíni víz, vagy felszíni víziüledék környezeti kockázatának csökkentése biológiai módszerekkel) területén vizsgáltak cianobaktériumokat is. Eredményeik rámutattak arra, hogy a vízoszlopon belüli, mozgásában korlátozott Chlorella és Anabaena törzsek N és $\mathrm{P}$ felvétele nagyobb, mint a mozgásukban szabad társaiké (RAI és MALLICK 1992). CHOI és mtsai. (1998) vizsgálatai szerint az Anabaena által termelt neutrális cukrokat, uronsavakat és proteineket tartalmazó flokulláns (pelyhesedést okozó) 
poliszaharid a káros elemek hatékony megkötését eredményezi. Az Anabaena subcylindrica Borge esetében ez a $\mathrm{Cu}, \mathrm{Co}, \mathrm{Pb}$ és $\mathrm{Mn}$, az Anabaena doliolium Bharadwaja esetében pedig az Fe és Cu megkötésében nyilvánult meg (GUPTA et al. 2013).

A cianobaktériumoknak fontos szerep jut az agro-biotechnológiában mind az integrált tápanyag-gazdálkodás, mind pedig a kártevők elleni védelem területén. A vízi és szárazföldi élőhelyek elsődleges benépesítőiként, kulcsszereplők a talajtermékenység egyensúlyának fenntartásában, illetve az élelmiszer-piramis alappilléreiként is számon tarthatók (PRASANnA et al. 2008). Észak- és KeletIndiában a rizsföldek vizsgálatakor olyan, a molekuláris nitrogén megkötésére képes nemzetségek domináns (40-90\%) jelenlétét mutatták ki, mint a Nostoc és az Anabaena (Prasanna és NAYA 2007 ).

A cianobaktériumok előnye a többi nitrogénkötővel szemben az, hogy míg a heterotróf szervezetek e tevékenységükhöz nagy mennyiségü hasznosítható szerves anyagot igényelnek, addig a cianobaktériumok szén-dioxidból és vízből, fixált szénigényüket is saját maguk fedezik. További előnyük, hogy a fixált nitrogénnek 5-88\%-át a környezetükbe leadhatják (PETERson 2001). Mutáns cianobaktérium törzs (Anabaena variabilis Kützing ex Bornet et Flahault) és búza nitrogénmentes tápoldatban történő együttes tenyésztése során a búza összes N-tartalma elérte a nitráttáplálású búzakontroll nitrogéntartalmának 85\%-át, emellett a cianobaktériumok fotoszintézise során kibocsátott oxigén elösegítette a búza gyökérlégzését vízkultúrában (SPILLER és GUNASEKARAN 1991). Rizskultúrákban a cianobaktériumok által fixált nitrogén mennyisége átlagosan évi $49 \mathrm{~kg} / \mathrm{ha}$-ra tehető. A szimbionta Anabaena azollae Strasburger cianobaktériumnak évi $30-80 \mathrm{~kg} / \mathrm{ha}$ nitrogénkötést tulajdonítanak, ez az érték pedig megegyezik a talajok diazotróf mikroszervezetei által fixált mennyiséggel (MetTing 1994).

Az Anabaena nemzetség egyes tagjainak antifungális (gombaölö) hatását is kimutatták. Az Anabaena laxa A. Braun kivonata, a „laxaphycin” hatásos volt 5, köztük az Aspergillus oryzae (Ahlb.) E. Cohn, Candida albicans (C. P. Robin) Berkhout és Penicillium notatum Thom gombára (Frankmölle et al. 1992). A Fusarium oxysporum f. sp. lycopersici (Sacc.) W. C. Snyder et H. N. Hans és a Fusarium moniliforme J. Sheld. ellen a paradicsomot komposzthoz adott Anabaena laxa törzzsel sikerült megvédeni (Prasanna et al. 2013). A fungicid hatású Anabaena laxa kezelés erősítette a növény védekezőképességét a növénypatogén gombával szemben. Kimutatták, hogy az Anabaena laxa hatásos fungicid vegyülete hasonlít a Lyngbya majuscula Harvey ex Gomont által termelt „majusculamid"-hoz (Gupta et al. 2013).

Az NYME-MÉK Növénybiológiai Intézetében anyagcseretermékeik felhasználhatósága kapcsán vizsgáltak Anabaena törzseket. ÖRDöG és mtsai. (1995) 
növényi növekedésszabályozó anyagokat (PGR) termelő algatörzsekkel kísérleteztek. Növekedésserkentés tekintetében, az Anabaena variabilis és az Anabaena cylindrica Lemmermann citokinin- és auxintermelése bizonyult a legígéretesebbnek. ÖRDöG és PULz (1995) az uborka sziklevélen végzett biotesztjei szemmel látható citokinin-szerü aktivitást mutattak az Anabaena torulosa Lagerheim ex Bornet et Flahault esetében is. MolnÁr és ÖRDöG (1996) nyolc Anabaena törzsből négy esetében mutattak ki citokinin-szerủ hatást az uborka sziklevél megnyúlási és/vagy a szója kallusz növekedési bioteszttel. Céljuk az volt, hogy a növénytermesztésben külső hormon forrásként alkalmazható törzseket találjanak. JÄGER és mtsai. (2010) sok más MACC törzs között az MACC 643 (Anabaena sp.) törzs kukoricára gyakorolt citokinin-, auxinszerü hatását vizsgálták.

A cianobaktériumok más mikroorganizmusokra gyakorolt növekedést serkentő és gátló hatását ugyancsak tanulmányozták. Figyelemre méltónak bizonyult kettő, saját gyüjtésű Anabaena sp. növekedést stimuláló hatása a Bacillus thuringiensis Kurstaki és Bacillus subtilis (Ehrenberg) Cohn fajokra nézve (SzIGETI et al. 1996). ÖRDÖG (1993) a szủrőtáplálkozású busa fajokkal etetési kísérleteket végzett alga- és cianobaktérium-tenyészeteket adva a halaknak. Az alkalmazott tenyészetek között az Anabaena flos-aquae Brébisson ex Bornet et Flahault fajt is vizsgálták. Szintén folytak kutatások Anabaena törzsek bevonásával, melyek során mezőgazdasági és gyógyszeripari (pl.: tumorellenes hatás) célra alkalmas algákat kerestek (ÖRDöG et al. 2004).

\section{A cianobaktériumok taxonómiai áttekintése}

A cianobaktériumok rendszere - mint más élőlénycsoportoké - állandó átalakuláson megy keresztül. A fajok osztályozását folyamatosan felülvizsgálják és átdolgozzák (KomáreK és ANAGNostidis 1986, 1989, ANAGNostidis és Komárek 1988, 1990, Turner 1997, Castenholz 2001). Az elmúlt években az ultrastrukturális tanulmányokból, ökológiai elemzésekből és különösen a molekuláris biológiából származó új adatok jelentősen megváltoztatták a cianobaktériumok taxonómiáját. A modern, polifázikus (kombinált) módszertani megközelítés a cianobaktériumok jobb azonosíthatóságát és sokféleségének pontosabb meghatározását teszi lehetővé (Korelusová 2008). Az egyik elterjedt osztályozási rendszer a cianobaktériumokat hat rendre osztja fel (CAVALIERSMITH 2002):

I. rend: Chroococcales (Wettstein 1924, átdolgozva RippKa et al. 1979, Joosten 2006,

II. rend: Gloeobacterales (CAVAlier-Smith 1998, átdolgozva CAVAlierSMITH 2002 által), 
III. rend: Nostocales (Geitler 1925, átdolgozva CASTENHOlz 1989, majd CAVAlier-Smith 2002 által),

IV. rend: Oscillatoriales (ELENKIn 1934, átdolgozva KomÁREK és ANAGNOSTIDIs 2005 által),

V. rend Pseudanabaenales (Lauterborn 1915, átdolgozva CavalierSMITH 2002 által),

VI. rend: Synechococcales (CAVALIER-SMith 2002 által),

$\mathrm{Az}$ Anabaena nemzetséget Bory de Saint-Vincent hozta létre 1822-ben, neve a görög „anabaino” szóból ered, ami „emelkedik, erősödik” jelentéssel bír (Bornet és Flahault 1886). Hagyományos értelemben az Anabaena nemzetség planktonikus és bentikus törzsek széles skáláját tartalmazta (GEITLER 1932, Elenkin 1938, Starmach 1966). A Geitler (1932) által közölt 57 Anabaena faj volt éveken keresztül a fö hivatkozási alap fajaik rendszertani besorolására. Az Anabaena Bory ex Bornet et Flahault nemzetség KoMÁREK és ANAGNostidis (1989) szerint a Nostocales rendhez tartozik. A közelmúltban a fonalas heterocitás cianobaktériumokhoz, a Nostocales rendbe és a Nostocaceae családba sorolták (RIPPKA et al. 2001).

\section{Az Anabaena taxonok morfológiai alapú rendszerezése}

Az Anabaena nemzetség morfológiai jellemzőit leíró korábbi közlemények korlátozott mértékben tértek ki a tenyésztési körülmények hatására (WILlame et al. 2006). Már régóta ismert, hogy a hosszú távú törzsfenntartás jelentős morfológiai változásokat okozhat a törzsekben (ANAND 1988). Így aztán téves lehet a morfológiai alapú azonosítás, ha az a természetből izolált cianobaktériumok tenyészetéből huzamosabb idő elteltével történik (KOMÁREK és ANAGNOSTIDIS 1989). A közlemények egy részének másik gyenge pontja az, hogy morfológiai adatok nélkül (leírás, méretek, mikrofotográfiák vagy rajzok) használják a klaszszikus fajneveket. Ezek azért keltenek zavart, mert az értelmezésük eltérhet különböző szerzők közléseiben (ZAPOMĚLOVÁ 2008). Nem egyértelmủ például az Anabaena circinalis Rabenhorst ex Bornet et Flahault és az Aphanizomenon flos-aquae Ralfs ex Bornet et Flahault morfológiai alapú megkülönböztetése (BELtRAN és NeILAN 2000), ugyanis a leírások alapján a két faj összetéveszthető egymással. Átfedések néhány más Anabaena faj leírásánál is megfigyelhetők.

FJERDINGSTAD (1966) az elsők között volt, aki felhívta a figyelmet arra, hogy az Aphanizomenon nemzetség könnyen összetéveszthető az Anabaena nemzetséggel. KoMÁREK és KováČıK (1989) értékelték a két nemzetség megkülönböztetésére használt morfológiai jellemzőket és egyetlen megbízható nemzetségspecifikus határozójegynek a trichómák struktúráját találták. 
RIPPKA és mtsai. (1979) megjegyezték, hogy a morfológiai határ az Anabaena és a Nostoc nemzetségek között sem minden esetben világos. A két nemzetség közötti különbség hagyományosan a kolóniaképzés jellegén alapult, de a Nostoc fajokra jellemző, természetes körülmények között képződő kocsonyás kolóniák ritkán alakulnak ki tenyészetekben. Az Anabaena nemzetség morfológiailag hasonlít a Nostoc Vaucher ex Bornet et Flahault nemzetséghez miközben a molekuláris eredmények azt mutatják, hogy ez a két nemzetség genetikailag jól elkülönül egymástól (RAJANIEMI et al. 2005a).

Az Anabaena nemzetség meglehetősen heterogén, mivel a nemzetségen belül két csoportot is megkülönböztethetünk, amelyek a planktonikus és a perifitikus életmódjuk (illetőleg életformájuk szerint lehetnek szoliter, klasztert alkotó vagy algaszőnyeget képző fajok), és különösen azon képességük alapján térnek el, hogy alkalmasak-e gázvakuólumok képzésére (KomÁREK és ANAGNOsTidis 1989). Ezek egyrészt a tipikus Anabaena fajok (Anabaena alnemzetség, A. oscillarioides Bory ex Bornet et Flahault típusú fajok, 1. ábra), melyek gázvakuólum nélküli filamentumokat hoznak létre, majd a szubsztrátumok felületén szőnyeget alkotva lebegnek vagy a talajban élnek. Másrészt pedig vannak a planktonikus Anabaena fajok (Dolichospermum alnemzetség Ralfs ex Bornet et Flahault). KOMÁREK és AnAgnostidis (1989) szerint ezek az Anabaena flos-aquae Brébisson ex Bornet et Flahault típusú fajok, melyek rendszerint szoliter trichómákként növekednek vagy trichómacsoportokban, gázvakuólumokkal (aerotópok). A jelenlegi molekuláris vizsgálatok eredményei azt mutatják, hogy a bentikus és a planktonikus Anabaena törzsek nem monofiletikusak. A planktonikus Anabaena törzseket egy egyesített klaszterbe helyezték az Aphanizomenon törzsekkel, arra utalva, hogy azok, a genetikai adatok szerint egyetlen nemzetségként kezelhetők (RAJANIEMI et al. 2005b).

\section{Heterociták és akinéták}

Néhány fonalas cianobaktériumnál, a fonal vegetatív sejtjeitől morfológiáját és funkcióját tekintve is eltérő két sejttípus található, a heterociták és az akinéták.

A heterocita a légköri nitrogénkötés helye, számából következtetni lehet a fixált nitrogén mennyiségére. A heterociták fizikailag a következőkben különböznek a vegetatív sejtektől: nagyobb méretűek, vastagabb a sejtfaluk és kevésbé szemcsés citoplazmájuk van (HASEL KORN 1978). A heterociták hosszúsága 5-17 $\mu \mathrm{m}$, szélessége pedig kb. 5-17 $\mu \mathrm{m}$ között alakul. A vegetatív sejtek hosszúsága

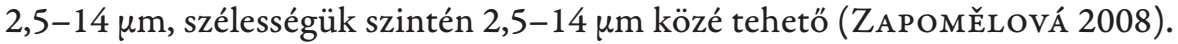

$\mathrm{Az}$ akinéta (görögül „akinetos”, ami mozdulatlant jelent) egyes cianobaktériumok nyugvó állapota, mely a kedvezőtlen körülmények hatásá- 




1. ábra. Anabaena oscillarioides Bory ex Bornet et Flahault típusfaj (KOMÁREK 1996).

Figure 1. Anabaena oscillarioides Bory ex Bornet et Flahault type species (KomÁreK 1996). 
ra alakul ki (ADAMS 2000). Az akinéták képesek ellenállni a hidegnek, a sötétségnek és a kiszáradásnak. Az akinéták hosszúsága (kb. 10-40 $\mu \mathrm{m}$ ) és szélessége (kb. 7-25 $\mu \mathrm{m})$ fajtól függően változhat, színük jellemzően sárgás, barnás (ZAPOMĚLOVÁ 2008). Az Anabaena nemzetség azonosításakor bizonyos jellemzők használata szerzőnként eltérhet. HiNDÁ (2000) például az Anabaena meghatározáshoz elsősorban az akinéták elhelyezkedését, a terminális sejtek alakját és a vegetatív sejtek átmérőjét használta. RAJANIEMI et al. (2005a) szerint a legfontosabb jellemzők az akinéták mérete és elhelyezkedése. STULP (1982) emellett a heterociták morfológiai jellemzőit, és az akinéták heterocitákhoz viszonyított elhelyezkedését is figyelembe vette.

\section{Anabaena taxonok molekuláris biológiai vizsgálatának eredményei}

Számos molekuláris megközelítést vezettek be és teszteltek széleskörűen. Ilyenek például a DNS-hibridizáció, az RFLP (restrikciós fragmenthossz-polimorfizmus) és a $16 S$ rRNS génszekvenciákon alapuló filogenetikai elemzés. Ez utóbbi bizonyult a leginkább alkalmazhatónak a hagyományos módszerekkel összevetve (PALINSKA et al. 2006). Jelenleg ez az elsődleges módszer a cianobaktérium kládok nemzetség szintủ meghatározásához. Várhatóan, következő lépésként a teljes genomok szekvenálása jellemzi majd a molekuláris módszereket (LARSSON et al. 2011).

A különböző Anabaena törzseknek eddig már számos genomrészletét szekvenálták (www.ncbi.nlm.nih.gov). Ezekből a szekvenciákból a $16 S$ rRNS, az ITS 1 , az rbcLX és a rpoB géneket vizsgálták részletesen és ez alapján vontak le taxonómiai következtetéseket (LI és Watanabe 2001, Gugger et al. 2002, RAJANiEMI et al. 2005a, 2005b, Will AmE et al. 2006). A vizsgálatok kimutatták, hogy az Anabaena és Aphanizomenon törzsek mind morfológiai mind molekuláris jellemzők alapján egymással átfedésben vannak és azok egyetlen nemzetséghez történő hozzárendelését javasolták (RAJANiEMI et al. 2005b). A Dolichospermum alnemzetséget Komárek és Anagnostidis korábban önálló planktonikus Anabaena csoportnak javasolták az Aphanizomenon nélkül (RAJANIEMI et al. 2005b). A jelenleg rendelkezésre álló szekvenciákból úgy tűnik a $16 S$ rRNS gén alkalmas a leginkább arra, hogy összehasonlítsunk morfológiai és molekuláris tulajdonságokat, legalább is a planktonikus Anabaena csoporton belül.

$\mathrm{Az}$ említett génszakaszok mellett, vizsgálják további gének alkalmazhatóságát is az Anabanea fajokat illetően. A nifH gén adatbázisa a mikroszervezetek egyik legnagyobb nem riboszomális adathalmaza (SINGH et al. 2013). A nifD gén ugyanilyen fontos gén, amely több lehetőséget biztosíthatna az egymással nagyon sok hasonlóságokat mutató nitrogénfixálók (Anabaena, Aphanizomenon) 
törzsfejlődésének és filogenetikai jellemzőinek megismeréséhez (ROESELERS et al. 2007).

Molekuláris adatokon alapuló filogenetikai vizsgálatok jelentős különbséget mutattak a baktériumszőnyeget képző bentikus és a gázvakuólumokkal rendelkező planktonikus fajok között. Ezen eredmények szerint a planktonikus Anabaena fajok közelebb állnak az Aphanizomenon-hoz, így azokat két nemzetségben különítették el: Dolichospermum és Sphaerospermopsis. Az eredeti Anabaena nemzetség az átdolgozás értelmében közelebb áll a Trichormus, a Nostoc, a Cylindospermum és Wollea nemzetségeket tartalmazó nagy kládhoz (az evolúció kladogram vagy fa ága), de pontos helye tisztázatlan (WERNER et al. 2012). Továbbá lehetséges ezen klaszter szeparálása, további nemzetségekbe való átalakítása. A planktonikus fajok leszűkült/elkeskenyedő sejtvégződéssel bíró csoportját (bennük eredetileg Anabaena és Aphanizomenon fajokkal) szintén elkülönült filogenetikai klaszterként kezelték, majd saját nemzetséget (Chrysosporum) hoztak létre nekik. A bentikus Anabaena sensu stricto klaszter tartalmaz elkeskenyedő trichómájú fajokat, főként trópusi élőhelyeken, amelyek nemzetség szintű elkülönítése ugyancsak lehetséges. Modern kutatási eredmények szerint a bentikus Anabaena fajok, melyek heterocitáinak mindkét oldalán van akinéta (ide tartozik a típusfaj, az Anabaena oscillarioides Bory ex Bornet et Flahault), közel állnak a Wollea nemzetséghez, így végeredmények itt csak további taxonómiai és nevezéktani változtatások után várhatók (KOMÁREK 2013).

A „Süßwasserflora von Mitteleuropa” (Közép-Európa Édesvízi Növényvilágának Határozókönyve) címü, a cianobaktériumok heterocitás nemzetségeit magába foglaló könyvsorozat legújabb, 2013-as kiadása szerint 30 európai és 30 Európán kívüli bentikus Anabaena faj elfogadott, illetve további 24 kerül említésre a „felülvizsgálatra váró fajok” kategóriában (KOMÁREK 2013). 116 korábban Anabaena nemzetség alatt szereplő taxon került át a következő nemzetségekbe:

A „planktonikus Anabaena"-khoz, vagyis a Dolichospermum (Ralfs ex Bornet et Flahault) Wacklin, Hoffman et Komárek 2009 nemzetséghez 49 faj tartozik, amiből 15 Európán kívüli a szerző szerint (WACKLIN et al. 2009). A felülvizsgálatra váró 7-ből pedig 6 fajneve még mindig Anabaena nemzetségnéven szerepel. ZАРОMĚLOvÁ és mtsai. (2011) a Dolichospermum nemzetségből 10 fajt különített el, azok akinétái ugyanis gömb alakúak és a heterocitákkal határosak, következésképpen számukra Sphaerospermopsis (ZАРомĚLová et al. 2010) néven új nemzetséget hoztak létre. A 10-ből 5 faj helyzete még mindig tisztázatlan, közöttük Anabaena és Aphanizomenon nemzetségnévvel ellátott fajok vannak. A Trichormus (Ralfs ex Bornet et Flahault) (KomÁrek és ANAGnostidis 1989) nemzetség, bár megjelenésében hasonló az Anabaena nemzetséghez, akinétaképző stratégiája teljesen eltérő és a Nostoc nemzetséghez közelít. 42 faj 
közül 4 még mindig Anabaena-ként van feltüntetve a „tisztázatlan” Trichormus fajok között. A Chrysosporum (ZAPOMĚLovÁ et al. 2011) nemzetség 15 faja közül 12 Anabaena volt korábban, a fennmaradó 3 pedig Aphanizomenon. A nemzetség érdekessége, hogy tisztán molekuláris szekvenálás által van elkülönítve.

\section{A polifázikus megközelítés}

A polifázikus megközelítés (kombinált módszertani megközelítést, amely a fajok meghatározásánál molekuláris, morfológiai, fiziológiai, citológiai, toxikológiai és ökofiziológiai adatokat is figyelembe vesznek) az egyik legígéretesebb módszer nagy mikrobaközösségek biológiai változatosságának elemzésére (KOMÁREK 2013).

A modern taxonómia célja olyan osztályozási rendszer készítése, amely tükrözi az evolúciós történetet. A cianobaktériumok az eubaktériumokhoz tartoznak, de a citomorfológiájuk, ökofiziológiájuk és a bioszférában betöltött funkciójuk világosan elkülöníti őket minden más eubaktériumtól (KOMÁREK 2006). Morfológiailag olyannyira változatosak, hogy még a molekuláris módszerek alkalmazása előtt is lehetséges volt a gondos, taxonokban gazdag alaktani besorolásuk. Ez pedig hozzájárult ahhoz, hogy megérthessük, mennyire bővelkedik cianobaktériumokban a bioszféra (BARKer et al. 1999). Azonban az elektronmikroszkópia, a részletes biokémiai tanulmányok, illetve különösen a molekuláris módszerek elterjedése olyan új strukturális és funkcionális ismereteket nyújtottak, melyek a fénymikroszkóp előtt mindvégig rejtve maradtak (FLETCHNER et al. 2002). Ennek eredményeként történt meg a már korábban említett 4 nemzetség (Dolichospermum, Trichormus, Chrysosporum, Sphaerospermopsis) Anabaena nemzetségből való elkülönítése is.

A cianobaktériumok sokféleségével kapcsolatos új ismereteink szintén megváltoztatták a rendszertani besorolásuk kritériumait, emellett genetikai hasonlóságok és a származástan specifikus, DNS-szekvencia alapú változata is elérhetővé vált (KOMÁREK 2006). A modern taxonómiának muszáj molekuláris eljárásokon is alapulnia, amelyekhez társulnak ultrastrukturális, morfológiai és ökofiziológiai karakterek, illetve a ma már nélkülözhetetlen és egyenrangú polifázikus megközelítésen alapuló jellemzők (CASAmATTA et al. 2006).

\section{Általános kihívások az Anabaena taxonok azonosításban}

A cianobaktériumok osztályozása még mindig a könnyen alkalmazható morfológiai és ökológiai jellemzőkkel történik. Minden egymást követő tudományos korszak egyre jobb módszereket nyújt - főként a molekuláris biológia. 
Sajnos, az új, molekuláris adatok nagy mennyiségének ellenére, még mindig sok a téves információ és hiba. Az adatokat online adatbázisban (NCBI, http:// www.ncbi.nlm.nih.gov/) gyüjtik össze, amelyek áttekinthetősége nem egyszerű. Gyakoriak a téves azonosítások, a taxonómiai és ökológiai adatok hiányosak. Sokszor még az ismert hibák sem kerülnek kijavításra. A legtöbb esetben, az új információk a rosszak mellé kerülnek, így eredményezve bonyolultabb helyzetet, ami jelentősen megnöveli az elemzések idejét. Ennek ellenére, az online adatbázisok hatalmas mennyiségű kihasználatlan információt kínálnak, de elemzésüket kritikus szemlélettel kell elvégezni (KoRELusová 2008).

A morfológusok napjainkban 84 Anabaena fajt tartanak nyilván (KOMÁREK és MAREs 2011), amelyből 24 tisztázatlan. Ezzel szemben az interneten fellelhető adatbázisok körülbelül 600 Anabaena faj létezését közlik. Egészen pontosan az ITIS (Integrált Taxonómiai Információs Rendszer, http://www.itis.gov/) 55, az Algabase (http://www.algaebase.org/) 503 az NCBI (Nemzeti Biotechnológiai Információs Központ, http://www.ncbi.nlm.nih.gov/) pedig 559 Anabaena fajról szolgáltat információt. Csupán 101 cianobaktérium taxon $16 \mathrm{~S}$ rDNS szekvenciáját határozták meg napjainkig. A molekuláris adatok nagyon fontosak taxonómiai és további filogenetikai vizsgálatokhoz. A cianobaktériumokból származó $16 S$ rDNS szekvencia izolálhatóságát sajnos olyan tényezők akadályozzák, mint a cianobaktériumok laboratóriumi környezetben történő tenyészthetőségének nehézségei vagy a monotipikus telepek természetben való korlátozott előfordulása. A monotipikus faj azt jelenti, hogy a kiterjedt area (elterjedési terület) ellenére külön alfajai nem ismertek. Ezen tényezők szintén magyarázatot adnak az eddig felfedezett fajok kisszámú szekvenciáira (KoRELUsová 2008).

JoHn és mtsai. (2002) alátámasztják, hogy az Anabaena taxonok rendszertani besorolás nagy biztonsággal csak akinéták jelenlétében végezhető el. Kulcsjellemzők közé sorolandó az akinéta alakja és mérete, és hogy a kitartósejt a heterocita mellett van-e, illetve ha igen, csak az egyik, vagy mindkét oldalon megtalálható? Megállapításaik szerint a természetből izolált minták nagy valószínűséggel mindig képeznek akinétákat, azonban ezen képességüket gyakran elvesztik laboratóriumi törzsfenntartásuk során, majdnem biztosan válaszként a genetikai változásokra. HoRI és mtsai. (2002) szerint egyes korlátozó tényezők (N-, P-, Fe-hiányos tápközeg) alkalmazása stresszhatást válthat ki és akinétaképzést eredményezhet.

Tapasztalataink alapján a legnagyobb kihívást az jelenti, hogy a vizsgálandó Anabaena törzsek nem axenikusak (steril), ami megnehezíti a DNS izolálást és a későbbi filogenetikai analízist. A probléma elhárítására ritkító szélesztést alkalmazunk, és a képződő szoliter telepeket vizsgáljuk molekuláris biológiai módszerekkel. 


\section{Következtetések}

Amint azt több szerző (CAStenholz és Norris 2005, KomÁreK 2006, Oren 2011) is kiemelte, a polifázikus megközelítés a legmegbízhatóbb lehetőség a cianobaktériumok azonosítására. Jelen tanulmány azonban rámutatott arra, hogy a molekuláris technikák alkalmazása annak ellenére, hogy gyorsan terjednek, a természetből izolált cianobaktérium minták pontos és végleges meghatározásában továbbra is kihívást jelent. Várható, hogy az egyre növekvő számú faj teljes genomszekvencia-adatai elérhetők lesznek, illetve hogy a GenBank adatbázisban (http://www.ncbi.nlm.nih.gov/genbank/) található tévesen azonosított szekvenciák fokozatosan kiszűrhetővé válnak, majd pedig a promóter génszakaszok is felülvizsgálatra és kizárásra kerülnek. Ezen teljes genomszekvenciakombinációk, valamint a cianobaktériumok azonosítását szolgáló alternatív módszerek segíteni fogják a meghatározást molekuláris szinten is. Azonban amíg ez nem történik meg, ezen mikroszervezetek pontos azonosítása továbbra is problematikus marad. Több molekuláris marker kombinációját kell használni a megfelelő filogenetikai elhatárolás érdekében. Sok, a múltban leírt faj közül jelenleg csupán néhány jól ismert és elfogadott, így mind több taxon szekvenálásával a rendelkezésre álló genomok száma is emelkedni fog és a közeljövőben további felülvizsgálatok várhatóak (KOMÁREK et al. 2014).

\section{Köszönetnyilvánítás}

Köszönettel tartozom prof. dr. Vörös Lajosnak az áttekintéshez kapcsolódóan megfogalmazott számos építő kritikai észrevételért és javaslatért, melyek nagyban hozzájárultak jelen publikáció végső formájának létrejöttéhez. A munka a TÁMOP-4.2.2.A-11/1/ KONV-2012-0003 „Mikroalga biotechnológia a fenntartható mezőgazdaságban” projekt keretében készült. A projekt az Európai Unió támogatásával, az Európai Szociális Alap társfinanszírozásával valósul meg.

\section{Irodalomjegyzék}

Adams D. G. 2000: Cyanobacterial phylogeny and development: questions and challenges. In: Brun Y. V., Shimkets L. J. (eds) Prokaryotic development. American Society for Microbiology, Washington, DC., pp. 51-81. http://dx.doi.org/10.1128/9781555818166.ch3

Ahmed M., Stal L. J., Hasnain S. 2010: Association of non-heterocystous cyanobacteria with crop plants. Plant and Soil 336: 363-375. http://dx.doi.org/10.1007/s11104-010-0488-x

Aknerman I., Janssen M., Rocha J., Wijffels R. H. 2002: Photobiological hydrogen production: photochemical efficiency and bioreactor design. International Journal of Hydrogen Energy 27: 1195-1208. http://dx.doi.org/10.1016/s0360-3199(02)00071-x

AnAgnostidis K., KomÁREK J. 1988: Modern approach to the classification system of cyanophytes. 3. Oscillatoriales. Archiv für Hydrobiologie, Supplement 80:327-472. 
ANAGNOSTIDIS K., KOMÁREK J. 1990: Modern approach to the classification system of cyanophytes. Teil 5, Stigonematales. Archiv für Hydrobiologie / Algological Studies 59: 1-73.

ANAND N. 1988: Culture studies and taxonomy of blue-green algae - certain identification problems. Archiv für Hydrobiologie Suppl. 80: 141-147.

Barker G. L. A, Hayes P. K., O'Mahony S. L., Vacharapiyasophon P., Walsby A. E. 1999: A molecular and phenotypic analysis of Nodularia (cyanobacteria) from the Baltic Sea. Journal of Phycology 35: 931-937. http://dx.doi.org/10.1046/j.1529-8817.1999.3550931.x

Beltran E. C., Neilan B. A. 2000: Geographical segregation of the neurotoxin-producing cyanobacterium Anabaena circinalis. Applied and Environmental Microbiology 66: 4468-4474. http://dx.doi.org/10.1128/aem.66.10.4468-4474.2000

Bornet, É., Flahault, C. 1886: Nostocacées Hétérocystées. (Anabaena). Annales des Sciences Naturelles, Botanique, Septième Série 7: 177-262.

Bryant, D. A. 1994: The Molecular Biology of Cyanobacteria. Kluwer Academic Publishers, Dordrecht, $879 \mathrm{pp}$.

Casamatta D. A., Gomez S. R., Johansen J. R. 2006: Rexia erecta gen. et sp. nov. and Capsosira lowei sp. nov., two newly described cyanobacterial taxa from the Great Smoky Mountains. Hydrobiologia 561: 13-26. http://dx.doi.org/10.1007/s10750-005-1602-6

Castenholz R. W. 1989: Subsection IV. Order Nostocales. In: Staley J. T., Bryant M. P., Pfennig N., Holt J. G. (eds) Bergey's Manual of Systematic Bacteriology, Vol. 3. Williams $\&$ Wilkins, Baltimore, Hong Kong, London, Sydney, pp. 1780-1793.

Castenholz R. W. 2001: Phylum BX. Cyanobacteria. In: Boone D. R., Castenholz R. W. (eds) Bergey's Manual of Systematic Bacteriology, 2nd ed, vol. 1. Springer, New York, pp. 473-487.

Castenholz R. W., Norris T. B. 2005: Revisionary concepts of species in the cyanobacteria and their applications. Archiv für Hydrobiologie (Suppl.) 159: 53-69.

Cavalier-Smith T. 1998: A revised six-kingdom system of life. Biological Reviews 73: 203-266. http://dx.doi.org/10.1111/j.1469-185x.1998.tb00030.x

CAVAlier-SMith T. 2002: The neomuran origin of archaebacteria, the negibacterial root of the universal tree and bacterial megaclassification. International Journal of Systematic and Evolutionary Microbiology 52: 7-76. http://dx.doi.org/10.1099/00207713-52-1-7

Cног C. W., Yoo S. A., Он I. H., PARK S. H. 1998: Characterization of an extracellular flocculating substance produced by a planktonic cyanobacterium, Anabaena sp. Biotechnology Letters 20: 643-646. http://dx.doi.org/10.1023/a:1005358204636

CHORUS I., BARTRAM J. 1999: Toxic cyanobacteria in water: a guide to their public health consequences, monitoring and management. E \& FN Spon, London, 416 pp.

Elen KIN A. A. 1934: Ob osnovnych principach sistemy Cyanophyceae. Soviet Botany 1934: 51-83.

ELENKIN A. A. 1938: Monographia algarum cyanophycearum aquidulcium et terrestrium in finibus URSS inventarum. (Sinezelenye vodorosli SSSR). Izd. AN SSSR, Moskva-Leningrad, Pars spec. 1-2, 1908 pp.

Fay P., Van BaAlen C. (eds) 1987: The Cyanobacteria. Elsevier, Amsterdam, 534 pp.

FJerdingstad E. 1966: Cell dimensions of some members of Aphanizomenon Morren (Cyanophyceae). Schweizerische Zeitschrift für Hydrobiologie 28: 133-147. http://dx.doi.org/10.1007/bf02502772

Fletchner V. R., Boyer S. L., Johansen J. R., DeNoble M. L. 2002: Spirirestis rafaelensis gen. et sp. nov. (Cyanophyceae), a new cyanobacterial genus from arid soils. Nova Hedwigia 74: 1-24. http://dx.doi.org/10.1127/0029-5035/2002/0074-0001

Frankmölle W. P., Larsen L. K., Caplan F. R., Patterson G. M. L., Knübel G., Levine I. A., Moore R. E. 1992: Antifungal cyclic peptides from the terrestrial blue-green alga 
Anabaena laxa. I. Isolation and biological properties. Journal of Antibiotics 45: 1451-1457. http://dx.doi.org/10.7164/antibiotics.45.1451

Geitler L. 1925: Synoptische Darstellung der Cyanophyceen in morphologischer und systematischer Hinsicht. Beihefte zum Botanischen Centralblatt 41: 163-294.

Geitler L. 1932: Cyanophyceae. Koeltz Scientific Books, Berlin.

Gugger M., Lyra C., Suominen I., Tsitko I., Humbert J. F., Salkinoja-Salonen M. S., SivoneN K. 2002: Cellular fatty acids as chemotaxonomic markers of the genera Anabaena, Aphanizomenon, Microcystis, Nostoc and Planktothrix (Cyanobacteria). International Journal of Systematic and Evolutionary Microbiology 52: 1007-1015.

http://dx.doi.org/10.1099/ijs.0.01917-0

Gupta V., Ratha S. K., Sood A., Chaudhary V., Prasanna R. 2013: New insights into the biodiversity and applications of cyanobacteria (blue-green algae) - Prospects and challenges. Review article. Algal Research 2: 79-97. http://dx.doi.org/10.1016/j.algal.2013.01.006

Haselkorn R. 1978: Heterocysts. Annual Review of Plant Physiology 29: 319-344. http://dx.doi.org/10.1146/annurev.pp.29.060178.001535

Hori K., Ishi S., Ikeda G., OKamoto J., Tanji Y., Weeraphasphong C., Unno H. 2002: Behavior of filamentous cyanobacterium Anabaena spp. in water column and its cellular characteristics. Biochemical Engineering Journal 10: 217-225.

http://dx.doi.org/10.1016/s1369-703x(01)00185-1

HiNDÁK F. 2000: Morphological variation of four planktic nostocalean cyanophytes - members of the genus Aphanizomenon or Anabaena? Hydrobiologia 438: 107-116. http://dx.doi.org/10.1023/a:1004118213936

JÄGER K., BARTóK T., ÖRDÖG V., BARNABÁs B. 2010: Improvement of maize (Zea mays L.) anther culture responses by algae-derived natural substances. South African Journal of Botany 76: 511-516. http://dx.doi.org/10.1016/j.sajb.2010.03.009

John D. M., Whitton B. W., Brook A. J. 2002: The freshwater algae of the British Isles. Cambridge University Press, Cambridge, 702 pp.

Joosten A. M. T. 2006: Flora of the blue-green algae of the Netherlands. 1. The non-filamentous species of inland waters. KNNV Publishing, Utrecht, 240 pp.

KOMÁREK J. 1996: Klíč k určování vodních květů sinic v České republice. [A key for determination of water-bloom-forming cyanobacteria in the Czech Republic]. In: MARŠÁLEK B., KERŠNER V., Marvan P. (eds) Vodní květy sinic. [Cyanobacterial water blooms], Nadatio flos-aquae, Brno, pp. 22-85 (in Czech).

KOMÁREK J. 2006: Cyanobacterial taxonomy: current problems and prospects for the integration of traditional and molecular approaches. Algae 21(4): 349-375.

http://dx.doi.org/10.4490/algae.2006.21.4.349

KoMÁREK J. 2013: Süßwasserflora von Mitteleuropa, Bd. 19/3: Cyanoprokaryota 3. Teil / 3rd part: Heterocytous Genera. Springer Spektrum.

Komárek J., Anagnostidis K. 1986: Modern approach to the classification system of cyanophytes. Teil 2. Chroococcales. Archiv für Hydrobiologie / Algological Studies 43: 157-226.

KomÁrek J., Anagnostidis K. 1989: Modern approach to the classification system of Cyanophytes, 4. Nostocales. Archiv für Hydrobiologie Suppl. 82: 247-345.

Komárek J., Anagnostidis K. 2005: Süsswasserflora von Mitteleuropa. Cyanoprokaryota: 2. Teil/2nd Part: Oscillatoriales. Elsevier Spektrum Akademischer Verlag, München, 19, 759 pp.

KomÁre K J., KovÁčı K L. 1989: Trichome structure of four Aphanizomenon taxa (Cyanophyceae) from Czechoslovakia, with notes on the taxonomy and delimitation of the genus. Plant Systematics and Evolution 164: 47-64. http://dx.doi.org/10.1007/bf00940429 
KomÁrek J., MARES J. 2011: An update to modern taxonomy (2011) of freshwater planktic heterocytous cyanobacteria. Hydrobiologia (2012) 698: 327-351. http://dx.doi.org/10.1007/s10750-012-1027-y

Komárek J., Kastovsky J., Mares J., Johansen J. R. 2014: Taxonomic classification of cyanoprokaryotes (cyanobacterial genera) 2014, using a polyphasic approach. Preslia 86: 295-335.

Korelusová J. 2008: Phylogeny of heterocytous Cyanobacteria (Nostocales and Stigonematales). University of South Bohemia, České Budějovice, 33 pp.

Larsson J., Nylander J. A., Bergman B. 2011: Genome fluctuations in cyanobacteria reflect evolutionary, developmental and adaptive traits. BMC Evolutionary Biology 11: 187. http://dx.doi.org/10.1186/1471-2148-11-187

LAUTERBORN R. 1915: Die sapropelische Lebewelt. Ein Beitrag zur Biologie des Faulschlammes natürlicher Gewässer. Verhandlungen des Naturhistorisch-Medizinischen Vereins zu Heidelberg ser. 2 13: 395-481, pl. III.

Li R., WatANABE M. M. 2001: Fatty acid profiles and their chemotaxonomy in planktonic species of Anabaena (Cyanobacteria) with straight trichomes. Phytochemistry 57: 727-731. http://dx.doi.org/10.1016/s0031-9422(01)00082-6

Metting F. B. 1994: Algae and cyanobacteria. In: Methods of Soil Analysis, Part 2. Microbiological and Biochemical Properties. SSSA, pp. 427-458.

MolnÁR Z., ÖRDög V. 1996: Cytokinin-like activity of eight Anabaena strains estimated by bioassays. Acta Agronomica Óváriensis 37: 137-142.

OREN A. 2011: Cyanobacterial systematics and nomenclature as featured in the International Bulletin of Bacteriological Nomenclature and Taxonomy / International Journal of Systematic Bacteriology / International Journal of Systematic and Evolutionary Microbiology. International Journal of Systematic and Evolutionary Microbiology 61(1): 10-15.

http://dx.doi.org/10.1099/ijs.0.018838-0

ÖRDöG V. 1993: Busaetetési kísérletek alga-és cyanobaktérium-tenyészetekkel. XVII. Halászati Tudományos Tanácskozás HAKI, Szarvas, pp. 1-8.

Ördög V., Molnár Z., Pulz O. 1995: Microalgal plant growth regulators (PGRs) for agricultural purposes. Conference on Plant in Vitro Culture in Memory of the 50th Anniversary of Gottlieb Haberlandts Death, September 1-3, 1995. Mosonmagyaróvár, pp. 1-6.

ÖRDöG V., Pulz O. 1995: Potential use of microalgae in the crop production. 2nd European Workshop Biotechnology of Microalgae, September 11-12, Bergholz-Rehbrücke, pp. 123-126.

Ördög V., Stirk W., Lenobel A., Bancírová R. M., Strnad M., Staden J. van, Szigeti J., NÉMETH L. 2004: Screening microalgae for some potentially useful agricultural and pharmaceutical secondary metabolites. Journal of Applied Phycology 16(4): 309-314. http://dx.doi.org/10.1023/b:japh.0000047789.34883.aa

Palinska K. A., Thomasius C. F., Marquardt J., Golubic S. 2006: Phylogenetic evaluation of cyanobacteria preserved as historic herbarium exsiccata. International Journal of Systematic and Evolutionary Microbiology 56: 2253-2263. http://dx.doi.org/10.1099/ijs.0.64417-0

Peterson P. (ed.) 2001: Biological soil crusts: ecology and management. Technical Reference $1730-2111$.

Prasanna R., Jaiswal P., Singh Y. V., Singh P. K. 2008: Influence of biofertilizers and organic amendments on nitrogenase activity and phototrophic biomass of soil under wheat. Acta Agronomica Hungarica 56: 149-159. http://dx.doi.org/10.1556/aagr.56.2008.2.4

PRASANNA R., NAYAK S. 2007: Influence of diverse rice soil ecologies on cyanobacterial diversity and abundance. Wetlands Ecology and Management 15: 127-134.

http://dx.doi.org/10.1007/s11273-006-9018-2 
Prasanna R., Chaudhary V., Gupta V., Babu S., Kumar A., Singh R., Shivay Y. S., Nain L. 2013: Cyanobacteria mediated plant growth promotion and bioprotection against Fusarium wilt in tomato. European Journal of Plant Pathology 136: 337-353.

http://dx.doi.org/10.1007/s10658-013-0167-x

Rai L. C., MALlick N. 1992: Removal and assessment of toxicity of Cu and Fe to Anabaena doliolum and Chlorella vulgaris using free and immobilized cells. World Journal of Microbiology and Biotechnology 8: 110-114. http://dx.doi.org/10.1007/bf01195827

Rajaniemi P., Hrouzek P., Kaštovská K., Willame R., Rantala A., Hoffmann L., KomÁrex J., Sivonen K. 2005a: Phylogenetic and morphological evaluation of the genera Anabaena, Aphanizomenon, Trichormus and Nostoc (Nostocales, Cyanobacteria). International Journal of Systematic and Evolutionary Microbiology 55: 11-26. http://dx.doi.org/10.1099/ijs.0.63276-0

Rajaniemi P., Komárek J., Willame R., Hrouzek P., Kaštovská K., Hoffmann L., SivoNEN K. 2005b: Taxonomic consequences from the combined molecular and phenotype evaluation of selected Anabaena and Aphanizomenon strains. Algological Studies 117: 371-391. http://dx.doi.org/10.1127/1864-1318/2005/0117-0371

Rippka R., DeReuelles J., Waterbury J. B., Herdman M., Stanier R. 1979: Generic assignments, strain histories and properties of pure cultures of cyanobacteria. Microbiology 111: 1-61. http://dx.doi.org/10.1099/00221287-111-1-1

Rippka R., Castenholz R. W., Herdman M. 2001: Subsection IV (formerly Nostocales Castenholz 1989b sensu Rippka, Deruelles, Herdman and Stanier 1979). In: Staley J. T., Bryant M. P., Pfennig N., Holt J. G. (eds) Bergey's manual of systematic bacteriology. Williams \& Wilkins Co., Baltimore, Md., pp. 562-566.

Roeselers G., Norris T. B., Castenholz R. W., Rysqaard S., Glud R. N., Kuhl M., MuYzer G. 2007: Diversity of phototrophic bacteria in microbial mats from Arctic hot springs (Greenland). Environmental Microbiology 9: 26-38. http://dx.doi.org/10.1111/j.1462-2920.2006.01103.x

Singh P., Singh S. S., Elster J., Mishra A. K. 2013: Molecular phylogeny, population genetics and evolution of heterocystous cyanobacteria using nif $\mathrm{H}$ gene sequences. Protoplasma 250 : 751-764. http://dx.doi.org/10.1007/s00709-012-0460-0

SPILlER H., GUNASEKARAN M. 1991: Simultaneous oxygen production and nitrogenase activity of an ammonia-excreting mutant of the cyanobacterium Anabaena variabilis in a co-culture with wheat. Applied Microbiology and Biotechnology 35: 798-804. http://dx.doi.org/10.1007/bf00169898

StARmaCH K. 1966: Cyanophyta-Sinice. Glaucophyta-Glaukofity. In: Starmach K. (ed.) Flora slodkowodna Polski. Tom 2., Panstwowe Wydawnictwo Naukowe, Warszawa, 807 pp.

STUlP B. K. 1982: Morphological variability of Anabaena strains (Cyanophyceae) under different culture conditions. Archiv für Hydrobiologie (Suppl.) 63: 165-176.

Szigeti J., Ördög V., Földes T., Pulz O. 1996: Microbial growth stimulation and inhibition caused by cyanobacteria. Conference on Progress in Plant Sciences from Plant Breeding to Growth Regulation, June 17-19, 1996. Mosonmagyaróvár, pp. 149-154.

TURner S. 1997: Molecular systematics of oxygenic photosynthetic bacteria. Plant Systematics and Evolution Suppl. 11: 13-52. http://dx.doi.org/10.1007/978-3-7091-6542-3_2

WACKLin P., Hoffmann L., Komárek J. 2009: Nomenclatural validation of the genetically revised cyanobacterial genus Dolichospermum (Ralfs ex Bornet et Flahault) comb. nova. Fottea 9(1): 59-64. http://dx.doi.org/10.5507/fot.2009.005

Werner V. R., Haywood D. R., Marli F. F., Célia L. S. A., Hoff C., De Souza Santos K. R., Neuhaus E. B., Molica R. J. R., Honda R. Y., Echenilue R. E. 2012: Morphological and 
molecular studies of Sphaerospermopsis torques-reginae (Cyanobacteria, Nostocales) from South American water blooms. Phycologia 51(2): 228-238.

http://dx.doi.org/10.2216/11-32.1

Wettstein R. 1924: Handbuch der systematischen Botanik. 1st ed. Franz Deuticke, Leipzig, $1071 \mathrm{pp}$.

Willame R., Boutte C., Grubisic S., Wilmotte A., Komárek J., Hoffmann L. 2006: Morphological and molecular characterization of planktonic cyanobacteria from Belgium and Luxembourg. Journal of Phycology 42: 1312-1332.

http://dx.doi.org/10.1111/j.1529-8817.2006.00284.x

ZAPOMĚLOVÁ E. 2008: Anabaena, phenotypic and genotypic diversity of planktonic strains in fishponds and reservoirs of the Czech Republic. PhD dissertation, Faculty of Science, University of South Bohemia, České Budějovice, 13 pp.

Zapomělová E., ŘehákovÁ-Kaštovská K., Jezberova J., KomÁrková J. 2010: Polyphasic characterization of eight planktonic Anabaena strains (Cyanobacteria) with reference to the variability of 61 Anabaena populations observed in the field. Hydrobiologia 639(1): 99-113. http://dx.doi.org/10.1007/s10750-009-0028-y

Zapomělová E., Hrouzex P., Rezanka T.,JezberováJ., Reháková K., Hisem D., Komár ková J. 2011: Polyphasic characterization of Dolichospermum spp. and Sphaerospermopsis spp. (Nostocales, Cyanobacteria): morphology, $16 \mathrm{~S}$ rRNA gene sequences and fatty acid and secondary metabolite profiles. Journal of Phycology 47: 1152-1163.

http://dx.doi.org/10.1111/j.1529-8817.2011.01034.x

\title{
REVIEW
}

\section{Taxonomic review and biotechnological applications of the cyanobacterial genus Anabaena}

\author{
N. HORVÁTH ${ }^{1}, Z_{\text {Z MOLNÁR }}^{1}$ and V. ÖRDÖG ${ }^{1,2}$ \\ ${ }^{1}$ Institute of Plant Biology, Faculty of Agricultural and Food Sciences, University of \\ West Hungary, H-9200 Mosonmagyaróvár, Lucsony str. 15-17; \\ horvathnandor@windowslive.com \\ ${ }^{2}$ University of KwaZulu-Natal, School of Biological Sciences, Pietermaritzburg Campus, \\ 3209 Scottsville, Private Bag X 01, South African Republic
}

Accepted: 25 February 2016

Key words: Anabaena, biotechnology, blue-green algae, cyanobacterium, phylogenetics, taxonomy.

Cyanobacteria have potential applications in diverse areas, especially in agriculture, as nutrient supplements in agriculture and industry. Their role as food supplements/nutraceuticals and in bioremediation and wastewater treatment is 
an emerging area of interest. In addition, they are known to produce a wide array of bioactive compounds with diverse biological activities. Cyanobacteria were originally classified mainly on the basis of morphological characteristics. The development of molecular techniques facilitated the use of morphological and molecular approaches at the same time. The current taxonomic studies are combined using the so called polyphasic approach, which takes molecular, morphological, physiological, cytological, toxicological and ecological data into account. To date, there are only a few well-known and accepted species among those which were discovered in the past, others need further revision. The taxonomy related book, Süßwasserflora von Mitteleuropa records approximately 84 Anabaena species. 116, previously Anabaena algae had been transferred to other genera. Now, 49 species belongs to Dolichospermum, 42 to Trichormus, 15 to Chrysosporum and 10 to Sphaerospermopsis genera. Anabaena genus can be found on Internet based databases as well. Algabase (http://www.algaebase.org/) contains 503 while NCBI (http://www.ncbi.nlm.nih.gov/) presents 559 Anabaena taxa.

The present review paper provides an overview of the species of Anabaena genus and its experimental and biotechnological application including the latest results of its taxonomic research. 